\title{
PENGGUNAAN MEDIA VISUAL DALAM MENINGKATKAN AKTIVITAS DAN KETERAMPILAN MENULIS LAPORAN
}

\author{
Ratna Sari Dewi Pohan ${ }^{1}$, Yuhelmi $\mathbf{W}^{2}$ \\ Universitas Muhammmadiyah Sumatera Barat ${ }^{1,2}$ \\ dewipohanmpd@gmail.com ${ }^{1}$
}

Submit, 05-11-2019 Accepted, 24-12-2019 Publish, 24-12-2019

\begin{abstract}
ABSTRAK
Penelitian ini bertujuan untuk mendeskripsikan peningkatan aktivitas dan keterampilan menulis laporan mahasiswa melalui media visual. Data penelitian ini berupa data kualitatif dan data kuantitatif. Metode penelitian menggunakan prosedur melalui tahapan: 1) observasi dan identifikasi masalah, 2) kegiatan pratindakan, 3) merencakan penelitian, 4) memilih pendekatan proses dengan menggunakan media visual untuk meningkatkan aktivitas dan nilai keterampilan menulis laporan, 5) membuat media pembelajaran visual tiga dimensi yang akan diproyeksikan melalui LCD proyektor, 6) membuat lembaran observasi, 7) melaksanakan penelitian (observasi, analisis dan refeksi). Kegiatan penelitian dilaksanakan 2 kali dengan tanpa menggunakan media visual dan dengan menggunakan media visual. Pengumpulan data dilaksanakan 2 peneliti dengan observer. Hasil penelitian menemukan bahwa setelah dilakukan penelitian, ternyata terdapat peningkatan proses dan nilai mahasiswa. Hasil penelitian menunjukkan peningkatan indikator aktivitas (rata-rata 60 dengan kualifikasi cukup (sebelum penggunaan media ), menjadi 80 dengan kualifikasi baik (sesudah penggunaan media). Peningakatan nilai dapat dilihat dari rata-rata 54,17 (sebelum) dengan kualifikasi hampir cukup menjadi 76.25 dengan kualifikasi baik (sesudah). Simpulan, penggunaan media visual mampu meningkatkan aktivitas dan nilai mahasiswa dalam menulis laporan berdasarkan objek visual.
\end{abstract}

Kata Kunci: Aktivitas, Keterampilan, Menulis, Laporan, Media Visual

\begin{abstract}
This study aims to describe the improvement of student report writing activities and skills through visual media. This research data in the form of qualitative data and quantitative data. Research procedures through stages: 1) observation and identification of problems, 2) pre-action activities, 3) planning research, 4) choosing a process approach using visual media to increase the activity and value of report writing skills, 5) making three-dimensional visual learning media to be projected through the $L C D$ of the projector, 6) making observation sheets, 7) implementing research (observation, analysis and reflection). Research activities were carried out 2 times without using visual media and using visual media. Data collection was carried out by 2 researchers with observers. The results of the study found that after the research was conducted, it appeared that there was an improvement in student processes and grades. The results showed an increase in activity indicators (an average of 60 with sufficient qualifications (before the use of the media), to 80 with good qualifications (after the use
\end{abstract}


of the media). Improved values can be seen from an average of 54.17 (before) with almost enough qualifications being 76.25 with good qualifications (after). This explains that visual media can improve student activities and grades in writing reports based on visual objects.

Keywords: Activities, Skills, Writing, Reports, Visual Media

\section{PENDAHULUAN}

Keterampilan menulis merupakan keterampilan berbahasa produktif. Keterampilan menulis sangat erat kaitannya dengan keterampilan berbahasa lainnya (menyimak, membaca, dan berbicara). Sebagai sebuah proses, keterampilan menulis mahasiswa akan dapat ditingkatkan dan dikembangkan melalui proses perkuliahan yang optimal oleh dosen (Sikumbang, 2014). Keterampilan menulis mahasiswa rendah. Pernyataan ini didasarkan pada observasi yang dilakukan pada saat pembelajaran, serta nilai yang diperoleh setelah membuat deskripsi berupa laporan. Sebagian besar mahasiswa kurang tertarik memahami, apalagi mengejarkan latihan menulis, sehingga dalam perkuliahan bahasa Indonesia khususnya pada materi pola pengembangan paragrafkhususnya kegiatan menulis laporan sebagai salah satu pengembangan tulisan deskripsi tidak sebagai mana mestinya. Terkesan bahwa mahasiswa cenderung tidak tertarik dengan materi menulis.Kurangnya baiknya aktivitas mahasiswa dalam perkuliahan menjadi pemicu rendahnya pemahaman tentang menulis yang baik sehingga laporan yang dibuatnya juga kurang baik.

Perkuliahan bahasa Indonesia hal yang membosankan bagi mahasiswa salah satu faktor umum penyebabnya adalah kehadiran mata ajaran ini yang terlalu sering (dari SD sampai SMA/SMK, ada pembelajaran bahasa Indonesia), serta materi yang berulang pada beberapa topik seperti halnya pada topik menulis. Di samping itu, berdasarkan wawancara dengan beberapa orang mahasiswa diketahui bahwa kejenuhan tersebut tidak terlepas dari penggunaan model pembelajaran guru mereka di sekolah yang kurang bervariasi sehingga berdampak di perguruan tinggi bagi proses dan hasil pembelajaran dosen. Para guru lebih banyak berkomunikasi menjelaskan materi menulis secara verbal melalui ceramah dan textbook oriented tanpa disertai latihandengan penggunaan media yang sesuai dengan materi.Keterlibatan siswa menjadi sangat minim, siswa hanya sebagai penerima informasi tanpa terlibat langsung dalam informasi 
tersebut. Ketika di perguruan tinggi, mahasiswa mengetahui ciri-ciri deskripsi (laporan), tetapi ketika dituntut untuk menuliskan/ membuat laporan sederhana mereka sulit.

Berdasarkan permasalahan tersebut, perlu disiasati kegiatan pembelajaran yang dapat membuat mahasiswa menjadi aktif (studend centered). Peran dosen bukan lagi pemberi informasi tetapi sebagai fasilitator dan organisator. Dalam proses perkuliahan mahasiswa dibantu dengan gambar visual yang dibuat semenarik mungkin dengan detail yang jelas sehingga memberikan motivasi yang lebih tinggi untuk mengobservasi objek tersebut dengan baik. Dengan bantuan memperkenalkan kosakata yang tepat dan sesuai, penerapan kaidah bahasa, serta kalimat efektif mahasiwa lebih mampu menulis laporan/deskripsi dengan lebihtepat. Penggunaan media visual dapat mempersempit ruang dan waktu tetapi tidak mengurangi hakikat dari objek yang dilaporkan mahasiswa.

Media merupakan alat bantu yang digunakan dosen yang dapat mempermudah mahasiswa memahami materi kuliah yang sukar dicerna dan dipahami terutama materi yang rumit dan kompleks (Arsyad, 2011). Penyampaian materi oleh dosen berpengaruh terhadap munculnya aktivitas dan pemahaman belajar yang ditunjukkan mahasiswa dari tulisannya. Salah satu alat yang dapat membantu dosen adalah media visual berupa slide gambar, video, dan gambar animasi yang diproyeksikan melalui LCD proyektor.

Penelitian terdahulu yang berkaitan dengan penelitian ini antara lain, Arnetti (2016) melihat kemampuan siswa dalam aktivitas menulis karangan deskripsi dengan memnggunakan peta konsep. Kemudian Lestari (2015) berfokus pada keterampilan menulis narasi dengan menggunakan model pembelajaran, sedangkan penelitian ini befokus pada aktivitas dan kreatifitas mahasiswa dalam menulis laporan melalui penggunaan media visual. Media visual merupakan alat bantu yang digunakan dosen yang dapat mempermudah mahasiswa memahami materi kuliah terutama materi yang rumit dan kompleks

\section{METODE PENELITIAN}

Penelitian ini tergolong dalam jenis penelitian tindakan,yang dikembangkan oleh Kemmis dan Taggart dengan sistem spiral refleksi. Alur penelitian tindakan dimulai dengan studi pendahuluan dalam bentuk kegiatan observasi pada proses dan hasil (nilai). Berdasarkan proses dan hasil tersebut dilaksanakan kegiatan perbaikan 
dengan penggunaan media visual dalam perkuliahan dengan materi menulis deskripsi/laporan berdasarkan media visual yang digunakan. Subjek penelitian adalah mahasiswa Fakultas Pariwisata Universitas Muhammadiyah Sumatera Barat NPM 2018, yang terdaftar pada tahun ajaran 2019/2020 sebanyak 36.. Penelitian dilaksanakan 2 kali yaitu pada 12 September dan 15 September 2019.

Prosedur penelitian melalui tahapan: 1). observasi dan identifikasi masalah, 2). kegiatan pratindakan, 3) merencakan penelitian, 4) memilih pendekatan proses dengan menggunakan media visual untuk meningkatkan aktivitas dan nilai keterampilan menulis laporan, 5) membuat media pembelajaran visual tiga dimensi yang akan diproyeksikan melalui LCD proyektor, 6) membuat lembaran observasi, 7) melaksanakan penelitian (observasi, analisis dan refeksi). Kegiatan penelitian dilaksanakan 2 kali dengan tanpa menggunakan media visual dan dengan menggunakan media visual. Pengumpulan data dilaksanakan 2 peneliti dengan observer.

\section{HASIL PENELITIAN}

Data yang dianalisis pada bagian berikut berkaitan data keberadaan aktivitas dan hasil belajar mahasiswa sebelum dan sesudah penggunaan media visual dalam membuat laporanberdasarkan media visual yang diperlihatkan sebagai berikut.

\section{Perbandingan Aktivitas Siswa sebelum dengan sesudah Penggunaan Media Visual}

Analisis data aktivitas siswa dalam perkuliahan dengan materi menulis laporan berdasarkan media visual dapat dilihat pada tabel berikut:

Tabel 1.

Aktivitas Siswa sebelum Penggunaan Media Visual

\begin{tabular}{clcrll}
\hline \multirow{2}{*}{ No. } & \multirow{2}{*}{ Jenis Aktivitas } & \multicolumn{2}{c}{ Frekuensi } & \multirow{2}{*}{ Keterangan } \\
\cline { 3 - 4 } & & Jumlah & \% & \\
\hline 1 & Memperhatikan penjelasan dosen & 27 & 75 & Lebih dari cukup \\
\hline 2 & Mencatat materi perkuliahan & 26 & 72,2 & Lebih dari Cukup \\
\hline 3 & Mengerjakan latihan & 22 & 61,1 & Cukup \\
\hline 4 & Mengajukan pertanyaan & 15 & 41 & Kurang \\
\hline 5 & Mengemukakan pendapat & 18 & 50 & Hamper cukup \\
\hline & Rata-rata & 21,6 & 60 & Cukup \\
\hline
\end{tabular}


Dari tabel di atas diketahui bahwa aktivitas mahasiswa dalam perkuliahanbahasa Indonesia untuk materi menulis laporan dengan tidak menggunakan media visual berupa gambar tiga dimensi rendah, dengan rata-rata kualifikasi cukup (60). Frekuensi aktivitas terendah pada aktivitas mengajukan pertanyaan (41\%) dan mengemukakan pendapat (50\%). Pada dasarnya mahasiswa memperhatikan penjelasan dosen $(75 \%)$ dan mencatat materi perkuliahan $(72,2)$. Dengan demikian usaha dosen untuk mengelola pembelajaran cukup baik.

Tabel 2

Aktivitas Mahasiswa sesudah Penggunaan Media Visual

\begin{tabular}{clcrl}
\hline \multirow{2}{*}{ No. } & \multirow{2}{*}{ Jenis Aktivitas } & \multicolumn{2}{c}{ Frekuensi } & \multirow{2}{*}{ Keterangan } \\
\cline { 3 - 4 } & & Jumlah & \% & \\
\hline 1 & Memperhatikan penjelasan dosen & 33 & 91.67 & Baik sekali \\
\hline 2 & Mencatat materi perkuliahan & 32 & 88.89 & Baik sekali \\
\hline 3 & Mengerjakan latihan & 36 & 100 & Sempurna \\
\hline 4 & Mengajukan pertanyaan & 19 & 52.78 & Hampir Cukup \\
\hline 5 & Mengemukakan pendapat & 24 & 66.67 & Lebih dari cukup \\
\hline & Rata-rata & 28.8 & 80 & Baik \\
\hline
\end{tabular}

Dari tabel di atas diketahui bahwa aktivitas mahasiswa dalam perkuliahanbahasa Indonesia untuk materi menulis laporan dengan menggunakan media visual berupa gambar tiga dimensi tinggi/meningkat, dengan kualifikasi rata-rata baik (80). Peningkatan dapat dilihat pada semua aktivitas walaupun peningkatan tertinggi pada aktivitas mengerjakan latihan (100\%).Hal ini didasarkan dengan adanya penggunaan media visual tersebut meningkatkan motivasi mahasiswa untuk memperhatikan objek yang diobservasi sebagai dasar untuk mengerjakan latihannya.Kualitas kemampuan menulis laporan mahasiswa sebelum dan sesudah penggunaan media visual berupa gambar tiga dimensi dapat dilihat pada tabel berikut:

Tabel 3.

Rekapitulasi Perolehan Nilai sebelum dan setelah Penggunaan Media Visual

\begin{tabular}{llllllll}
\hline \multicolumn{7}{l}{ Perolehan Nilai/Tingkat Kemampuan } \\
\hline \multicolumn{7}{l}{ Sebelum Penggunaan Media Visual } & \multicolumn{4}{l}{ Setelah Penggunaan Media Visual } \\
\hline No & KS & Nilai & Kualifikasi & No & KS & Nilai & Kualifikasi \\
& & & & & & \\
\hline 1 & 001 & 60 & Cukup & 1 & 001 & 85 & Baik \\
\hline 2 & 002 & 74 & Lebih dari cukup & 2 & 002 & 88 & Baik sekali \\
\hline 3 & 003 & 45 & Kurang & 3 & 003 & 72 & Lebih dari cukup \\
\hline 4 & 004 & 50 & Hampir cukup & 4 & 004 & 75 & Lebih dari cukup \\
\hline
\end{tabular}




\begin{tabular}{|c|c|c|c|c|c|c|c|}
\hline 5 & 005 & 55 & Hampir cukup & 5 & 005 & 70 & Lebih dari cukup \\
\hline 6 & 006 & 61 & Cukup & 6 & 006 & 78 & Baik \\
\hline 7 & 007 & 50 & Hampir cukup & 7 & 007 & 76 & Baik \\
\hline 8 & 008 & 50 & Hampir cukup & 8 & 008 & 70 & Lebih dari cukup \\
\hline 9 & 009 & 71 & Lebih dari cukup & 9 & 009 & 84 & Baik \\
\hline 10 & 010 & 70 & Lebih dari cukup & 10 & 010 & 88 & Baik sekali \\
\hline 11 & 011 & 40 & Kurang & 11 & 011 & 60 & Cukup \\
\hline 12 & 012 & 45 & Kurang & 12 & 012 & 71 & Lebih dari cukup \\
\hline 13 & 013 & 50 & Hampir cukup & 13 & 013 & 75 & Lebih dari cukup \\
\hline 14 & 014 & 59 & Cukup & 14 & 014 & 78 & Baik \\
\hline 15 & 015 & 78 & Baik & 15 & 015 & 84 & Baik \\
\hline 16 & 016 & 45 & Kurang & 16 & 016 & 70 & Lebih dari cukup \\
\hline 17 & 017 & 45 & Kurang & 17 & 017 & 72 & Lebih dari cukup \\
\hline 18 & 018 & 50 & Hampir cukup & 18 & 018 & 78 & Baik \\
\hline 19 & 019 & 54 & Hampir cukup & 19 & 019 & 71 & Lebih dari cukup \\
\hline 20 & 020 & 73 & Lebih dari cukup & 20 & 020 & 73 & Lebih dari cukup \\
\hline 21 & 021 & 60 & Cukup & 21 & 021 & 82 & Baik \\
\hline 22 & 022 & 52 & Hampir cukup & 22 & 022 & 75 & Lebih dari cukup \\
\hline 23 & 023 & 55 & Hampir cukup & 23 & 023 & 78 & Baik \\
\hline 24 & 024 & 55 & Hampir cukup & 24 & 024 & 63 & Cukup \\
\hline 25 & 025 & 50 & Hampir cukup & 25 & 025 & 72 & Lebih dari cukup \\
\hline 26 & 026 & 40 & Kurang & 26 & 026 & 70 & Lebih dari cukup \\
\hline 27 & 027 & 44 & Kurang & 27 & 027 & 73 & Lebih dari cukup \\
\hline 28 & 028 & 51 & Hampir cukup & 28 & 028 & 81 & Baik \\
\hline 29 & 029 & 72 & Lebih dari cukup & 29 & 029 & 70 & Lebih dari cukup \\
\hline 30 & 030 & 62 & Cukup & 30 & 030 & 80 & Baik \\
\hline 31 & 031 & 45 & Kurang & 31 & 031 & 70 & Lebih dari cukup \\
\hline 32 & 032 & 45 & Kurang & 32 & 032 & 70 & Lebih dari cukup \\
\hline 33 & 033 & 50 & Hampir cukup & 33 & 033 & 85 & Baik \\
\hline 34 & 034 & 54 & Hampir cukup & 34 & 034 & 79 & Baik \\
\hline 35 & 035 & 50 & Hampir cukup & 35 & 035 & 76 & Baik \\
\hline 36 & 036 & 40 & Kurang & 36 & 036 & 68 & Lebih dari cukup \\
\hline \multicolumn{2}{|c|}{ Rata-rata } & 54,17 & Hampir cukup & & & 76,25 & Baik \\
\hline
\end{tabular}

Berdasarkan tabel di atas dapat diketahui bahwakemampuan menulis laporan mahasiswa Fakultas Pariwisata Universitas Muhammadiyah Sumatera Barat sebelum penggunaan media visual. Persentasi tingkat kemampuan dengan kualifikasi kurang diperoleh 10 orang $(27,77)$. Kualifikasi hampir cukup diperoleh 15 orang $(41,66)$. Kualifikasi cukup diperoleh 5 orang (13.88). Kualifikasi lebih dari cukup diperoleh 5 orang $(13,88)$. Kualifikasi baik diperoleh 1 orang $(2,77)$.Persentasi tingkat kemampuan menulis laporan mahasiswa Fakultas Pariwisata Universitas Muhammadiyah Sumatera Barat setelah penggunaan media visual dalam menulis laporan: kualifikasi cukup diperoleh 2 orang $(5,55)$. Kualifikasi lebih dari cukup diperoleh 18 orang $(50,00)$. Kualifikasi baik diperoleh 14 orang $(38,88)$. Kualifikasi baik sekali diperoleh 2 orang $(5,55)$. 


\section{PEMBAHASAN}

Menulis adalah salah satu dari empat keterampilan berbahasa yang memerlukan keterampilan yang kompleks.Menulis sangat erat kaitannya dengan keterampilan berbahasa lainnya (menyimak, berbicara, dan keterampilan membaca).Menulis merupakan keterampilan produktif (menghasilkan tulisan).Dengan demikian, keberhasilan menulis yang terlihat dari kualitas tulisan tersebut sangat dipengaruhi kualitas keterampilan lainnya.Laporan merupakan salah satu pengembangan tulisan berupa deskripsi. Oleh karena itu ciri deskripsi melekat pada laporan yakni: 1) berupaya untuk lebih memperlihatkan detail atau perincian tentang objek, 2) lebih bersifat memberikan pengaruh sensitivitas dan membentuk imajinasi pembaca, 3) disampaikan dengan gaya memikat dengan pilihan kata yang menggugah, 4) lebih banyak memperlihatkan sesuatu yang dapat didengar, dilihat dan dirasakan, 5) organisasi penyajian umumnya mengikuti susunan ruang (Semi, 2005).Berdasarkan analisis data yang terlihat pada tabel 1 dan 2 diketahui bahwa terdapat peningkatan aktivitas mahasiswa dalam proses perkuliahan dengan penggunaan media visual. Sebelum penggunaan media, kualifikasi rata-rata semua aktivitas 60 (cukup).Dengan penggunaan media visual, aktivitas mahasiswa dalam perkuliahan menulis laporan meningkat dengan rata-rata 80 (baik). Hal ini menjelaskan bahwa kehadiran media dalam proses perkuliahan dapat meningkatkan motivasi mahasiswa ke arah yang lebih baik karena terjadi peningkatan 20\%. Dengan demikian, sesungguhnya setiap dosen menggunakan media dalam setiap pembelajarannya.

Berdasarkan analisis data pada tabel 3 terlihat peningkatan perolehan nilai dan kualifikasi keterampilan menulis laporan berdasarkan media visual tiga dimensi. Perolehan nilai sebelum penggunaan media, rata-rata 54,17 dengan kualifikasi hampir cukup, dan setelah penggunaan media visual menjadi rata-rata 76, 25 dengan kualifikasi baik. Data ini menjelaskan bahwa keberadaan media visual tiga dimensi dapat meningkatkan pemahaman tentang objek yang akan dilaporkan dalam tulisan mahasiswa $(22,08 \%)$.

Dapat disimpulkan, aktivitas perkuliahan yang baik akan mempengaruhi pada kualitas hasil (nilai). Kehadiran penggunaan media sangat memegang peranan penting dalam meningkatkan kualitas perkuliahan.Perkuliahan yang mengandalkan uraian verbal saja (ceramah) cenderung membosankan bagi mahasiswa. Sebaliknya jika uraian 
verbal tersebut diperkuat dengan penggunaan media akan dapat meningkatkan aktivitas dan nilai mahasiswa. Dengan demikian usaha dosen mengadakan media berbanding lurus dengan pencapaian nilai yang lebih baik bagi mahasiswanya.

\section{SIMPULAN}

Berdasarkan hasil analisis data dapat disimpulkan bahwa 1) terdapat peningkatan aktivitas mahasiswa dalam perkuliahan bahasa Indonesia, 2) terdapat peningkatan kemampuan/nilai rata-rata menulis laporan, 3) penggunaan media visual dapat meningkatkan aktivitas dan keterampilan menulis laporan

\section{DAFTAR PUSTAKA}

Arnetti, A. (2016). Peningkatan aktivitas dan kemampuan menulis karangan deskripsi melalui pengunaan peta konsep pada Siswa, Jurnal Konseling Indonesia. (http://jurnal.konselingindonesia.com)

Arsyad, A. (2011). Media Pembelajaran. Jakarta :Rineka Cipta.

Semi, M., A. (2005). Menulis Efektif. Bandung. Angkasa.

Sikumbang, R. (2004). Kalimat Efektif. Jakarta. Gramedia.

Tri, P.,L. (2015) Peningkatan keterampilan menulis narasi melalui model pembelajaran Wholelanguage dengan Audiovisual. Joyful Learning Journal. (http.//journal.unnes.ac.id/sju/index.php/jlj) 